\title{
Photochromic Materials by Postpolymerisation Surface Modification
}

\author{
Shuyun Chng, \\ ${ }^{\dagger}$ Department of Chemistry, Chemistry Research Laboratory, The University of Oxford, 12-Mansfield Road, Oxford OX1 3TA, \\ United Kingdom \\ ${ }^{\ddagger}$ Singapore Institute of Manufacturing Technology, 2 Fusionopolis Way, \#08-04, Innovis, Singapore 138634
}

\section{Supporting Information}

ABSTRACT: Photochromic materials are available by a postpolymerization surface modification of diverse polymers in a multistep sequential process mediated, first, by carbene insertion chemistry, second, by diazonium coupling with a tethered precursor, and finally by coupling to a spiropyran.

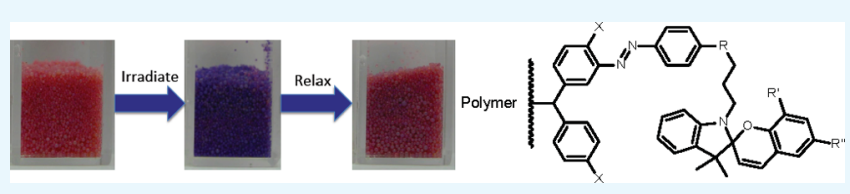
This three-step sequence is efficient, and surface loading densities of $10^{13}$ molecules $\mathrm{cm}^{-2}$ are typically achievable, leading to materials with observable photochromic and wettability behavior, which operate over multiple cycles without significant photobleaching or loss of efficacy. Materials suitable for application in this process include both reactive, but also lower surface energy polymers. Although the process is particularly efficient for high surface area materials, surface modification onto lower surface area substrates, while being intrinsically less efficient, is nonetheless sufficiently effective that changes in macroscopic photochromic properties are readily observable.

\section{INTRODUCTION}

Photochromophores can be interconverted reversibly between two (meta)stable states upon irradiation at different wavelengths, usually as a result of cis-/trans-photoisomerisation and/ or photocyclisation. ${ }^{1}$ Photoresponsive polymers incorporating the azo-group 1 (Figure 1) have found wide application, ${ }^{2}$ so that light-modified biosensing, ${ }^{3}$ self-assembly behavior, ${ }^{4}$ and the delivery of bioactive molecules have all been reported., Alternatively, spiropyrans 2a (Figure 1$)^{7,8}$ have been widely used in organic photochromic switches for their reversible decolouration-colouration ${ }^{9}$ since UV photoirradiation gives the ring-opened, colored merocyanine form $\mathbf{2 b}$, which may revert to the closed, colorless spiropyran form 2a under visible light or by thermal relaxation in the dark..$^{10-12}$ In addition to these photochromic changes, the conversion of the hydrophilic, zwitterionic, merocyanine form to the hydrophobic spiropyran form also causes a significant change in polarity, which is manifested as a change in surface wetting behavior. ${ }^{13}$ With their energetically accessible and kinetically favorable ring openingring closure behavior, ${ }^{14-16}$ sensitivity, and readily accessible synthesis, ${ }^{17-19}$ spiropyrans have been used to introduce hydrophobicity and surface wetting, ${ }^{20-23}$ electrical switching, $^{24,25}$ cell binding, ${ }^{26}$ small molecule binding (e.g., cyanide receptor ${ }^{27,28}$ ), and photoresponsive and optical sensor effects, $^{21,29,30}$ suitable for a wide range of applications. ${ }^{31}$ Photochromic groups have been used to introduce lightinitiated macroscopic effects into polymers, ${ }^{2,8,19,32-36}$ but of interest to us was whether surface modification of a polymer alone provided both the level of loading and stability of chromophore to achieve a suitably functional material. For such polymer surface modification, we have shown that substituted diaryldiazomethanes ${ }^{37}$ and bisdiaryldiazomethanes ${ }^{38}$ may be used to introduce macroscopic properties, including visible chromophoric, ${ }^{39}$ fluorescent, ${ }^{40}$ biocompatible, ${ }^{41}$ protein adhe- sive, ${ }^{42,43}$ biocidal, ${ }^{44-46}$ hydrophobic, ${ }^{47,48}$ metal chelation, ${ }^{49}$ copolymerization, ${ }^{50}$ crosslinking, ${ }^{44}$ and end group ${ }^{51}$ effects, onto a wide variety of substrates, ${ }^{45}$ with a loading of the diarylmethyl unit onto the material surface of the order of $3 \times 10^{14}$ molecules $\mathrm{cm}^{-2} \cdot{ }^{37}$ Although this approach compares favorably to alternatives, ${ }^{5}$ a key question relates to whether the surface loading density arising from this type of chemical modification is sufficient to impart a wider range of observable macroscopic phenomena. We report here the results of some investigations to apply this process for the introduction of surface photochromic behavior, in which a spiropyran moiety is attached to the surface of polymers using a covalent chemical linkage.

\section{RESULTS AND DISCUSSION}

Bis(dimethylamino)- and dimethoxydiaryldiazomethanes (3a,b respectively, Scheme 1) have been found to be very effective for surface modification, offering an appropriate balance of reactivity and stability. ${ }^{37}$ These were readily prepared using the literature protocol; ${ }^{37}$ whereas dimethoxydiaryldiazomethane could be kept for up to 6 months at $0{ }^{\circ} \mathrm{C}$ if shielded from light before use, bis(4-(dimethylamino))diaryldiazomethane needed to be used more rapidly as it would decompose within 2 weeks under the same conditions. These materials were dissolved in $\mathrm{Et}_{2} \mathrm{O}$ and coated onto XAD4 polystyrene (PS) beads by physisorption by careful removal of solvent. After heating of the dried physisorbed polymer to 120 ${ }^{\circ} \mathrm{C}$, the modified materials, XAD4.A1 and XAD4.A2 (Scheme 1 ), were obtained; this reaction proceeds by collapse of the diazo function with loss of nitrogen gas, to give an intermediate, but

Received: September 26, 2018

Accepted: October 29, 2018

Published: November 15, 2018 


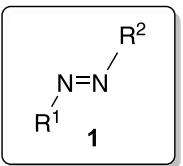

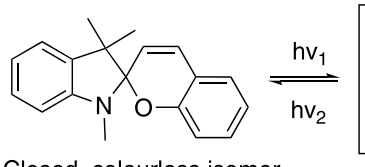

Closed, colourless isomer (Spiropyran) 2a

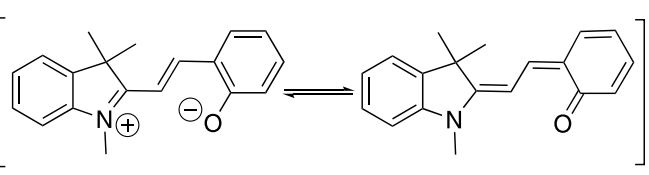

Open, coloured isomer (Merocyanine) 2b

Figure 1. Photochromism from spiropyran-merocyanine equilbration.

\section{Scheme 1}

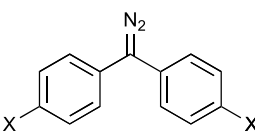

3a $X=-\mathrm{NMe}_{2}$ 3b $X=-O M e$

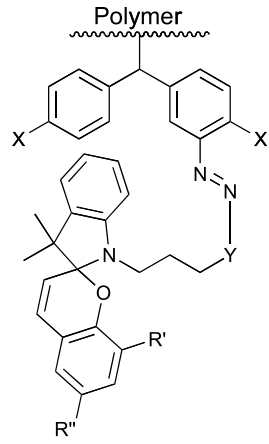

Polymer:

XAD4 $=$ polystyrene $\mathrm{XAD}-4$

$\mathrm{PC}=$ polycarbonate

$\mathrm{PET}=$ polyethylene terephthalate PET = polyethylene terephthalate
LDPE = low density polyethylene LDPE = low density polyethylene
UHMWPE = ultra high molecular weight polyethylene

PDMS = polydimethoxysilane

$\mathrm{PC}=$ polycarbonate

TPU = thermoplastic polyurethane $\mathrm{COC}=$ cyclic olefin copolymer PMMA = polymethyl methacrylate

$\mathrm{PS}=$ polystyrene

$\mathrm{PP}=$ polypropylene

(iii)

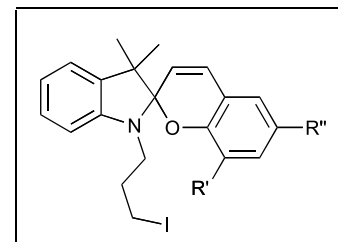

5a $\mathrm{R}^{\prime}=\mathrm{H}, \mathrm{R}^{\prime \prime}=\mathrm{NO}_{2}$

5b $\mathrm{R}^{\prime}=\mathrm{R}^{\prime \prime}=\mathrm{Br}$

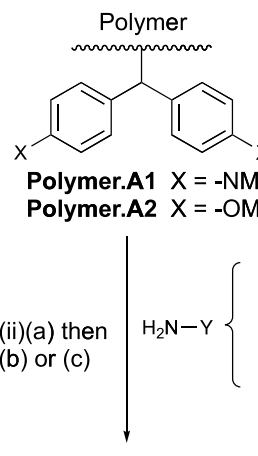

Ax $=$

A1 $\mathrm{X}=-\mathrm{NMe}_{2}$

A2 $\mathrm{X}=-\mathrm{OMe}$

$\mathrm{Y}=-\mathrm{C}_{6} \mathrm{H}_{4} \mathrm{CH}_{2} \mathrm{OH}$

4b $\mathrm{Y}=-\mathrm{C}_{6} \mathrm{H}_{4} \mathrm{CH}_{2} \mathrm{COOH}$

4c $\mathrm{Y}=-\mathrm{C}_{6} \mathrm{H}_{4} \mathrm{OH}$

4d $Y=-\mathrm{C}_{6} \mathrm{H}_{4} \mathrm{COOH}$

4e $Y=$
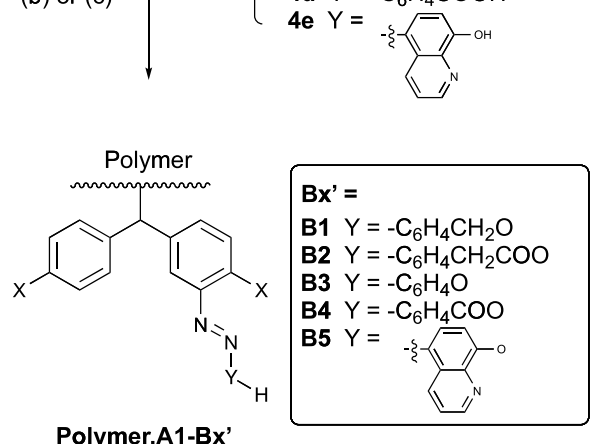

Polymer.A1-Bx

Polymer.A2-Bx'

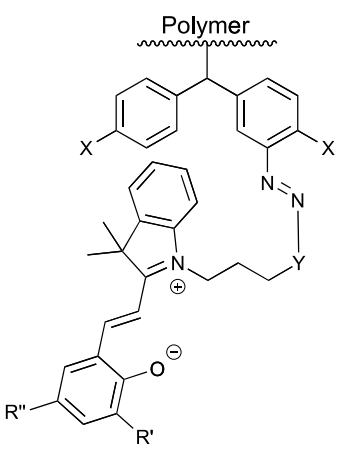

Conditions: (i) Polymer, $\mathrm{Et}_{2} \mathrm{O}$, heat at $120^{\circ} \mathrm{C}$; (ii)(a) $\mathrm{RNH}_{2}, \mathrm{NaNO}_{2}, \mathrm{THF}: \mathrm{H}_{2} \mathrm{O}=1: 1,3 \mathrm{M} \mathrm{HCl}, 0^{\circ} \mathrm{C}$ then (b) $0^{\circ} \mathrm{C}-$ R.T. or (c) $0^{\circ} \mathrm{C}-\mathrm{R}$.T, NaOAc; (iii) $5 \mathrm{a}$ or b, reflux in $\mathrm{MeCN}$ with $\mathrm{K}_{2} \mathrm{CO}_{3}$.

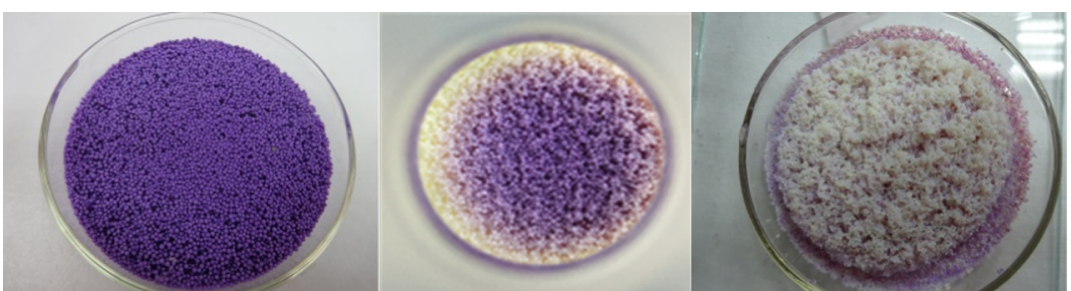

Figure 2. (Left to right): PS XAD4 beads coated with $3 \mathbf{b}$ before, during thermolysis, and after UV irradiation.

highly reactive carbene. ${ }^{37}$ A change in color from green (for 3a) or purple (for $\mathbf{3 b}$ ) (see Figure 2) to pale yellow or colorless beads indicated the completion of the surface modification. For XAD4.A1, yellow colouration of the beads, along with a UV peak absorbance in reflection of $380 \mathrm{~nm}$, indicated that surface modification leading to the introduction of aromatic systems had occurred (Table S1, Supporting Information). Successful modification was also evident from the IR spectrum, where the 
Scheme 2

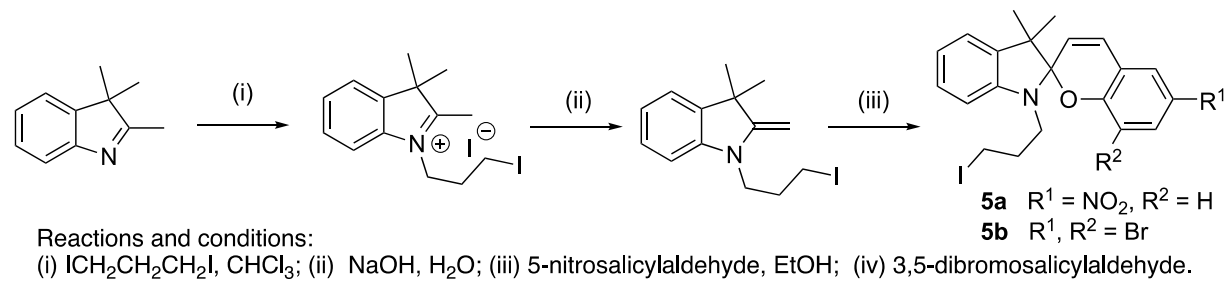

new peaks at 1349 and $1173 \mathrm{~cm}^{-1}$ corresponding to the $\mathrm{C}-\mathrm{N}$ bond modified onto the surface were clearly observed. Both combustion and X-ray photoelectron spectroscopy (XPS) analysis confirmed the presence of nitrogen, with an estimated surface coverage of $(2.1 \pm 0.5) \times 10^{13}$ molecules $\mathrm{cm}^{-2}$ for the former, and an $\mathrm{N}$-to- $\mathrm{C}$ ratio of 0.0436 for the latter gave a surface loading value of $37 \%$ assuming a monolayer formation. Comparison of corresponding data for the unmodified starting $\mathrm{XAD} 4$ polystyrene (PS) beads provides clear evidence for successful surface modification (Table S1, Supporting Information). The presence of nitrogen provided a very useful marker to demonstrate qualitatively and quantitatively that surface modification had occurred.

A variety of diazonium salts was then investigated for the conjugation of new chemical functionality onto these preactivated polymers XAD4.Ax $(x=1,2)$ and this gave the surface-modified beads XAD4.Ax-B $x^{\prime}\left(x=1-2, x^{\prime}=1-5\right.$, Scheme 1 and Table S2, Supporting Information). The diazonium salts were generated from the required amines $4 a-$ e by stirring with $\mathrm{NaNO}_{2}$ in $\mathrm{THF} / \mathrm{H}_{2} \mathrm{O}=1: 1$ in acidic conditions at $0{ }^{\circ} \mathrm{C}$ for $30 \mathrm{~min}$ and were used in situ; this step was done in the absence or presence of $\mathrm{NaOAc}$, since buffering has been found to be beneficial for coupling in some cases. ${ }^{52}$ Controls derived from blank XAD4 beads (XAD4.B $\boldsymbol{x}^{\prime}, x^{\prime}=1-$ 5 ), which omitted the intermediate carbene step, were prepared for comparison purposes (Table S2, Supporting Information). The visible color of the beads gave an immediate indication of modification, and this was confirmed by diffused reflectance UV-vis (absorbance mode) spectroscopy, which gave spectra with absorbances less than $520 \mathrm{~nm}$ for the most intensely colored materials. In general, the $\mathrm{n} \rightarrow \pi^{*}$ transition of an isolated azo group $(\mathrm{R}-\mathrm{N}=\mathrm{N}=\mathrm{R})$ has $\lambda_{\max }$ around $340 \mathrm{~nm},{ }^{53}$ but the extra conjugation of an adjacent aromatic ring leads to a bathochromic shift; for this reason, all of samples XAD4.A1$\mathbf{B} \boldsymbol{x}^{\prime}$ have $\lambda_{\text {max }}$ greater than $340 \mathrm{~nm}$ (Table S2 and Figure S1a,b, Supporting Information). Importantly, the use of $\mathrm{NaOAc}$ gave better azo-coupling efficiency, as indicated from a hyperchromic effect consistent with a greater density of chromophores at the polymer surface, an outcome which was similar to reactions in solution. ${ }^{52}$ In some cases, attenuated total reflection-infrared (ATR-IR) spectroscopic analysis was sufficiently sensitive to give conclusive evidence for modification (e.g., XAD4.A2-B2 and XAD4.A2-B4 from the presence of a carbonyl group at around 1701 and $1744 \mathrm{~cm}^{-1}$, respectively). Both combustion and XPS analysis confirmed the presence of nitrogen; the former indicated loading levels of $4.8 \times 10^{12}$ up to $3 \times 10^{13}$ molecules $\mathrm{cm}^{-2}$, and in the latter a surface loading value of up to $78 \%$ assuming full monolayer formation was observed. The presence of nitrogen provided a very useful marker to demonstrate qualitatively and quantitatively that surface modification had occurred in this step. For beads XAD4.A1, second-stage modification B4 gave the best loading (15\%), and B5 the worst $(8.2 \%)$, as shown by combustion analysis, and this is also consistent with the XPS data, which showed that the $\mathrm{N}$ to $\mathrm{C}$ ratio for XAD4.A1-B4 was 0.0843, whereas that for XAD4.A1-B5 was 0.0215. Both modifications B4 using XAD4.A1 and XAD4.A2 resulted in similar extents of azo coupling, with estimated surface coverages of the total surface area of 15 and 17\% for beads XAD4.A1-B4 and XAD4.A2-B4, respectively.

These activated polymers were reacted further with alkyl halides $\mathbf{5 a}, \mathbf{b}$, prepared by modification of the literature methodology starting from 2,3,3-trimethylindolenine (Scheme $2),{ }^{17,28}$ by refluxing beads XAD4.Ax-B $\boldsymbol{x}^{\prime}$ with $\mathrm{K}_{2} \mathrm{CO}_{3}$, to give the surface-modified materials XAD4.Ax-B $\boldsymbol{x}^{\prime}-\mathbf{C} \boldsymbol{x}^{\prime \prime}$ (Scheme $1)$. These were characterized as before by a combination of UVvis spectroscopy, ATR-IR, combustion analysis, and XPS (Table S3, Supporting Information). Intense visible and UV chromophores and IR absorptions confirmed that the expected surface derivatization had occurred (e.g., XAD4.A2-B5-C1), although in some cases, color change resulting from hybridization with spiropyrans $\mathbf{5} \mathbf{a}, \mathbf{b}$ was not immediately evident (e.g XAD.A2-B4-C1), since the starting beads were already intensely colored. This was confirmed in the UV-vis data (Figure S2a, Supporting Information), where the change in absorbance intensity from XAD4.A2-B4 to XAD4.A2-B4C1 was only 0.05 at $450 \mathrm{~nm}$, whereas that for XAD4.A2-B5 to XAD4.A2-B5-C1 was about 0.42 at $350 \mathrm{~nm}$. Different side groups on the spiropyran gave different chromophoric absorptions; thus, surface modification with a spiropyran containing the $\mathrm{NO}_{2}$ moiety (C1) gave a more purple pink colouration, whereas modification with the dibromo moieties (C2) gave a green blue, arising from the different levels of conjugation in the aromatic residues. This can be seen in the UV-vis spectra (Figure S2a,b, Supporting Information), where peaks for sample XAD4.A2-B5-C1 appeared at 524, 555, and $653 \mathrm{~nm}$ and for samples XAD4.A1-B5-C2 at $600 \mathrm{~nm}$. The presence of nitrogen and bromine (where relevant) was indicated from combustion analysis; quantitation of nitrogen and bromine gave similar loading values, which were typically in the range of $10^{12}$ molecules $\mathrm{cm}^{-2}$. XPS analysis gave further independent confirmation of the presence of these elements, and gave surface loading values of up to $70 \%$, assuming full monolayer coverage. It should be noted that differences in surface loading data between estimated by combustion analysis or XPS arise because the former includes nitrogen of the bulk, whereas XPS more nearly estimates the surface loading. Both values, however, are of value since they provide lower and upper bounds, respectively, for the estimation of the material loading after modification. As before, this data taken together confirmed the success of modification leading to the inclusion of spirocyclic systems at the surface.

Substrate Scope. With the general surface modification procedure optimized using PS XAD4, the substrate scope was investigated, and the sequence shown in Scheme 1 was applied to poly(ethylene terephthalate) (PET) pellets, low density polyethylene (LDPE) powder, and ultrahigh-molecular-weight 
polyethylene powder (UHMWPE) (Table S4, Supporting Information); their surface area was determined by BrunauerEmmett-Teller analysis (Table S5, Supporting Information). The low surface area of these materials, along with their lower intrinsic chemical reactivity when compared to XAD4, was the reason for their selection for study, and directly impacted upon the observed modification, which gave weaker color intensity. However, that the modification had been made was evident for LDPE, which has the highest surface area of these materials, from UV-vis and ATR-IR spectroscopic analyses where the expected signals were observed. However, UHMWPE powder was not useful for ATR-IR characterization due to its large particle size, although it did give excellent diffused reflectance UV-vis data (Figure S3a, Supporting Information), exhibiting a peak at around $350 \mathrm{~nm}$, corresponding to the azo chromophore. The change in UV-vis spectra of surface-modified UHMWPE powders could be tracked during the evolution of the surface modification process from UHMWPE.A2, UHMWPE.A2-B4, and UHMWPE.A2-B4-C1 (Figure S3b, Supporting Information); the peak at around $350 \mathrm{~nm}$ is due to the azo chromophore and that around $560 \mathrm{~nm}$ for UHMWPE.A2-B4-C1 to the spiropyran, illustrating the superposition of chromophores in the modified substrates. PET pellets were difficult to characterize by both ATR-IR spectroscopy and UV-vis spectrophotometry as a result of sample handling difficulties due to their large particle size. The ATR-IR spectra indicated peaks corresponding to the surface modification, in contrast to the blank polymer (Table S4, Supporting Information); for example, successful azo coupling for LDPE.A2-B2 was evident with clear $\mathrm{C}=\mathrm{O}$ peaks at around $1742 \mathrm{~cm}^{-1}$. Elemental combustion analysis characterization, for which $\mathrm{N}$ content was typically below the detection limit of $0.1 \%$, did confirm the presence of nitrogen in some cases (e.g., PET.A2-B2). XPS data could be used to estimate surface coverage of the modification; again LDPE powder gave a better outcome as a result of its higher surface area, and LDPE.A2-B4 and LDPE.A2-B4-C1 gave an $\mathrm{N}$ to $\mathrm{C}$ ratio that indicated a surface coverage of approximately 10.2 and $18.5 \%$, respectively.

Having demonstrated the application of surface modification to these materials, further extension of the modification strategy (that is, elaboration of the starting material by application of modifications $\mathrm{A} x$ to $\mathrm{B} x^{\prime}$ to $\left.\mathrm{C} x^{\prime \prime}\right)$ to flat substrates was made (Scheme 1 and Table S4, Supporting Information). Flat PS, polycarbonate (PC), polypropylene (PP), and cyclic olefin copolymer (COC) were all produced by injection molding, thermoplastic polyurethane (TPU), and poly(dimethoxysilane) (PDMS) sheets were from solvent casting, whereas poly(ethylene terephthalate) (PET) and poly(methylmethacrylate) sheets were commercially available. Because of the larger size of polymer sample in these cases, the diaryldiazo precursor $\mathbf{3 b}$ required for modification A was most conveniently applied as a spray in a volatile solvent, and its derived carbene was generated via photolysis using a high intensity UV conveyor belt system; successful achievement of modification A2 was apparent by a change from opaque purple of the physisorbed material to a clear yellow color. For modification B, diazonium salts were synthesized from amines $\mathbf{4 a}-\mathbf{e}$ in ethanol rather than a mixture of THF and water to avoid polymer degradation, and the freshly prepared diazonium salt in cold solution was poured over the substrates and left to stand in an ice bath for $18 \mathrm{~h}$. Modification of $\mathrm{C}$ was achieved by treatment with a mixture of spiropyran 6a,b and $\mathrm{K}_{2} \mathrm{CO}_{3}$ in dimethyl sulfoxide (DMSO) for $5 \mathrm{~h}$. The decolourisation resulting from the initial carbene insertion was readily apparent in the modification of PDMS (Figure 3). The ATR-IR, XPS, and contact angle characterization data for the

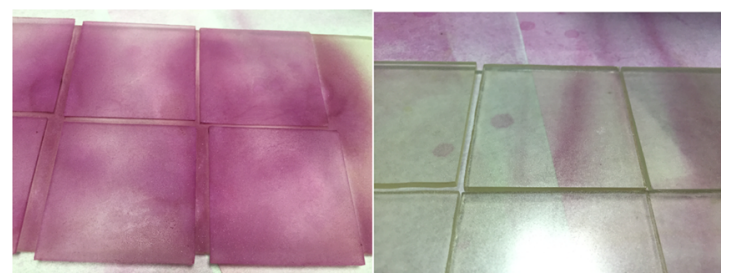

Figure 3. Flat PDMS sheets spray coated with diaryldiazo $\mathbf{3 b}$ before (left) and after (right) UV irradiation.

modified polymers are given in Table S6 and Figures S4-S10 (Supporting Information), whereas a significant color change was not always evident after surface modification, ATR-IR and XPS analyses clearly confirmed the introduction of the expected surface chemical functionality in all cases. By contrast to powder substrates, water contact angle (WCA) could be readily monitored, and changes to surface polarity were readily evident. For example, a decrease of about $5.6^{\circ}$ for WCA was measured for both PET.A2-B2 and PET.A2-B4 relative to PET.A2, and for TPU.A2-B2 and TPU.A2-B4 relative to TPU.A2, a much greater decrease in angles of 21.4 and $18.5^{\circ}$, respectively, was found, due to the introduction of a polar $\mathrm{COOH}$ group onto the polymer surface (Figure 4). Further modification of TPU.A2$\mathbf{B} 2$ to give TPU.A2-B2-C1 also gave an increase in WCA as the $\mathrm{COOH}$ groups on the TPU surface were further hybridized with spiropyrans that are not as polar in their closed-ring form.

Photochromicity: Surface Behavior. Polymers with surface-modified photochromic spiropyran (Scheme 1) were then investigated for photochromic activity. XAD4 PS beads proved to be an ideal system for this study, both for their high surface area and loading, but also their macroscopic form. XAD4 samples with diamino surface modification A1 (samples XAD4.A1-B4-C1, XAD4.A1-B5-C1, XAD4.A1-B5-C2) generally showed little change in color before and after UV irradiation, and this was confirmed from the corresponding UV-vis spectra (Table S7, Supporting Information); this might be due to an inappropriate chromophore for absorption. However, XAD4.A1-B5-C1 did give a change in color after irradiation (Table S7 and Video S1, Supporting Information), and in the UV-vis spectrum there was an increase in absorbance in the region $500-650 \mathrm{~nm}$ and especially $\lambda_{\max }$ at around $575 \mathrm{~nm}$. This outcome clearly indicated that a nitro-substituted spiropyran is superior than the bromo one for visible photochromic change, and this most likely arises from the greater conjugation in the former system. Visible color change, however, was much more apparent for systems with modification A2 (Figure 5 and Table S7 (Supporting Information)), consistent with a stronger chromophore and/ or better coupling efficiency in the modification protocol. The change in color for XAD4.A2-B5-C1 was particularly apparent, with a clear transformation from pink-to-blue after UV irradiation, a change which increased with longer irradiation time and with significant increases in absorbances at 353 and $560 \mathrm{~nm}$ in the UV spectrum (Figure S4, Supporting Information). Although the appearance of XAD4.A2-B5-C2 did not indicate a clear change in color after UV irradiation, absorption spectra nonetheless showed new peaks at around 350,554 , and $645 \mathrm{~nm}$. The UV-vis spectra of photochromic spiropyran-modified XAD4 beads showed that change in 


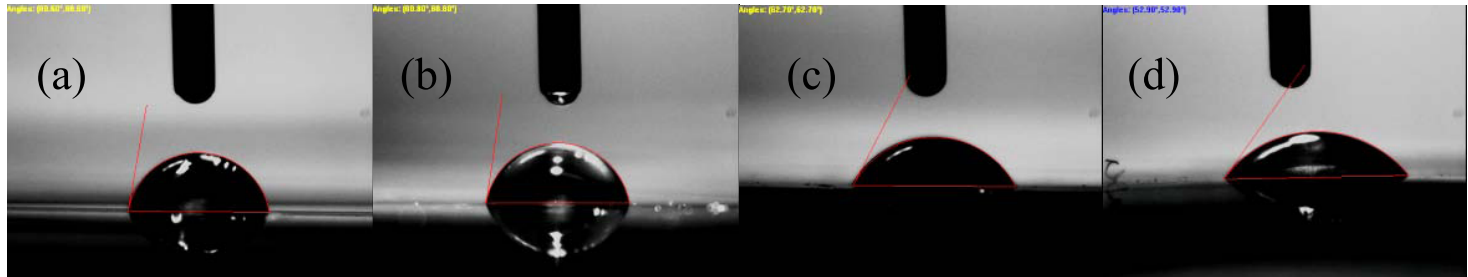

Figure 4. Water contact angle of surface-modified TPU (a) TPU.Blank; (b) TPU.A2; (c) TPU.A2-B2; (d) TPU.A2-B4.
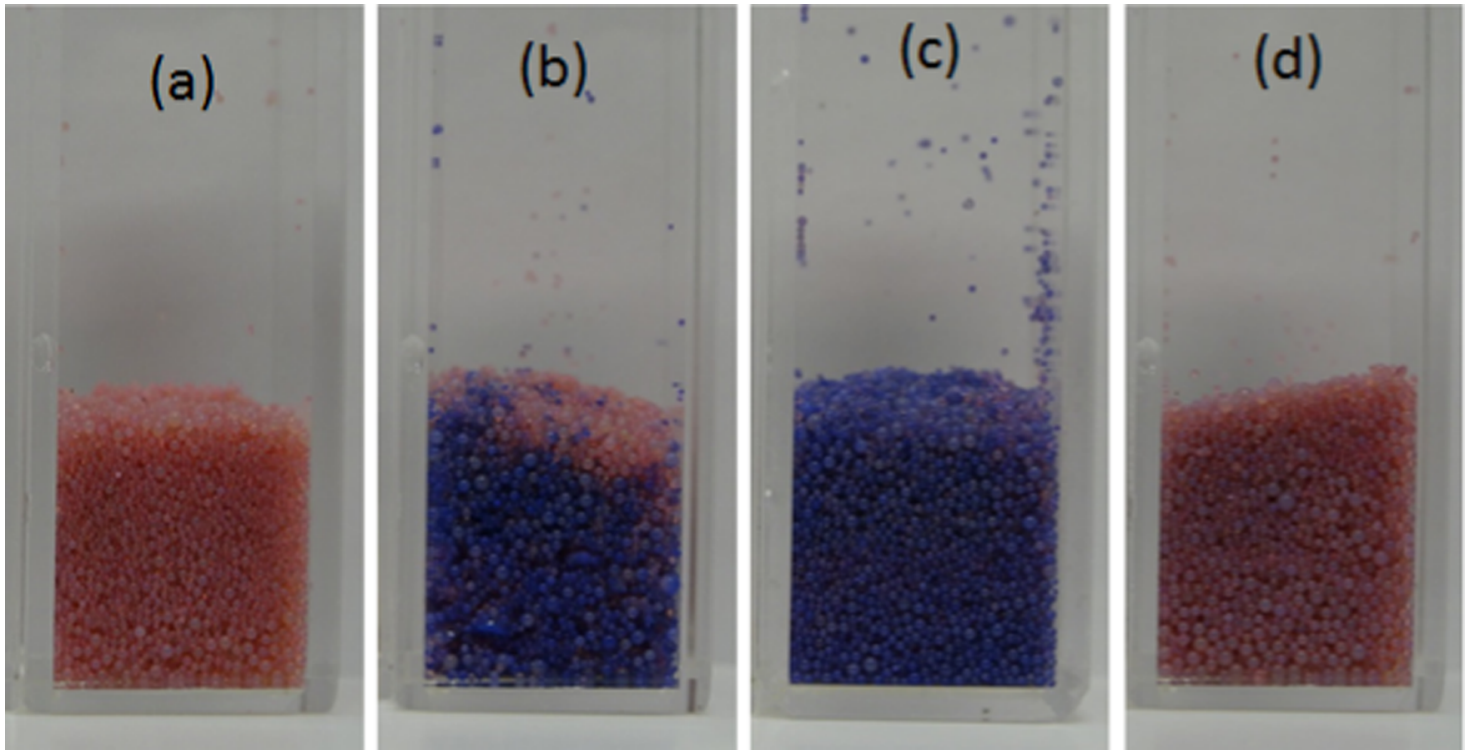

Figure 5. Photochromic behavior of surface-modified polystyrene XAD4.A2-B5-C1 (samples in $1 \mathrm{~cm}$ cuvettes). (a) Before UV irradiation; (b) after UV irradiation for $5 \mathrm{~s}$; (c) after UV irradiation for $30 \mathrm{~s}$; (d) upon relaxation for $60 \mathrm{~min}$.

\section{Scheme 3}

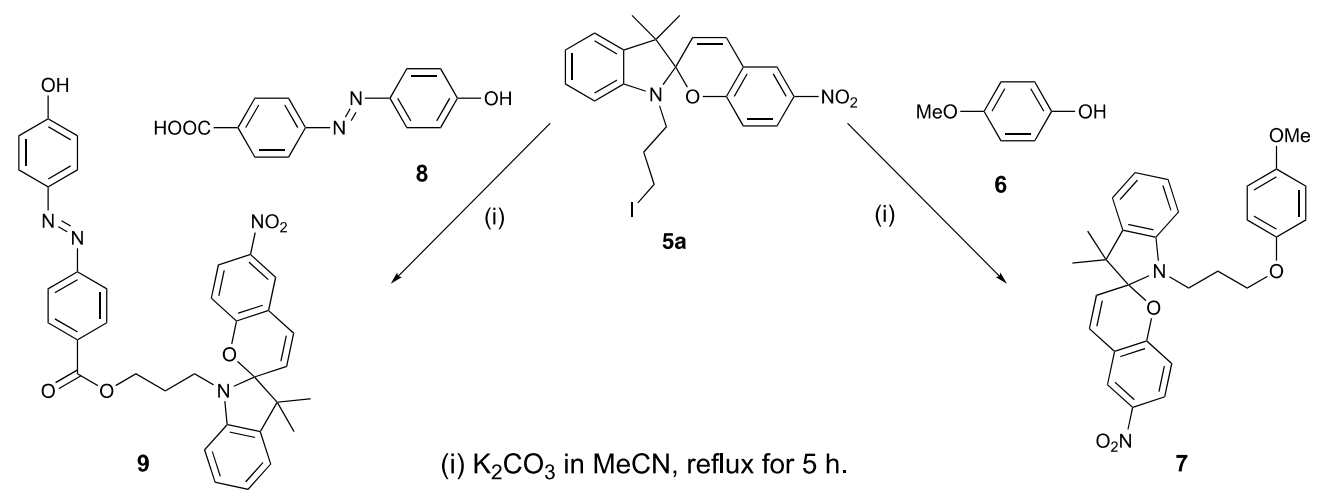

absorption spectra occurred most significantly at 500-650 nm, consistent with ring opening of the spiropyran to give the highly colored merocyanine form.

This outcome was compared to analogous soluble systems 7 and 9, prepared from spiropyran 5a and phenols 6 and 8 (Scheme 3) and for which solution UV-vis spectra could be obtained. The spiropyran unit 5a usually displayed conversion from colorless-to-blue in a change that is clearly solventdependent (Figure S11 and Video S2, Supporting Information) and which arose from increased absorbance in the region centered around 480-500 nm (Figure S12a,b, Supporting Information). Compounds 7 and 9 gave burgundy-to-blue and pink-to-red color changes, respectively (Figure S13a,b, Supporting Information), arising from significant changes in intensity of peaks at 480 and 530, respectively; these solution color changes mirror those seen on the XAD surface, with the red-to-blue of compound 7 also occurring for XAD4.A2-B5-C1 and therefore providing direct evidence for the formation of the expected chromophore on the polymer surface. The color change for compound 9 in solution (Figure S13a,b, Supporting Information) and its solid-phase partner XAD4.A2-B5-C1 was significantly less and illustrates the need for careful optimization of coupling chemistry and chromophore generation in this methodology. More importantly, the time for relaxation was significantly different between solution and surface, being considerably slower on the surface than in solution (e.g., XAD4.A2-B5-C1 took more than $1.5 \mathrm{~h}$ to relax compared to less than $10 \mathrm{~min}$ for the solution analog 7 and 


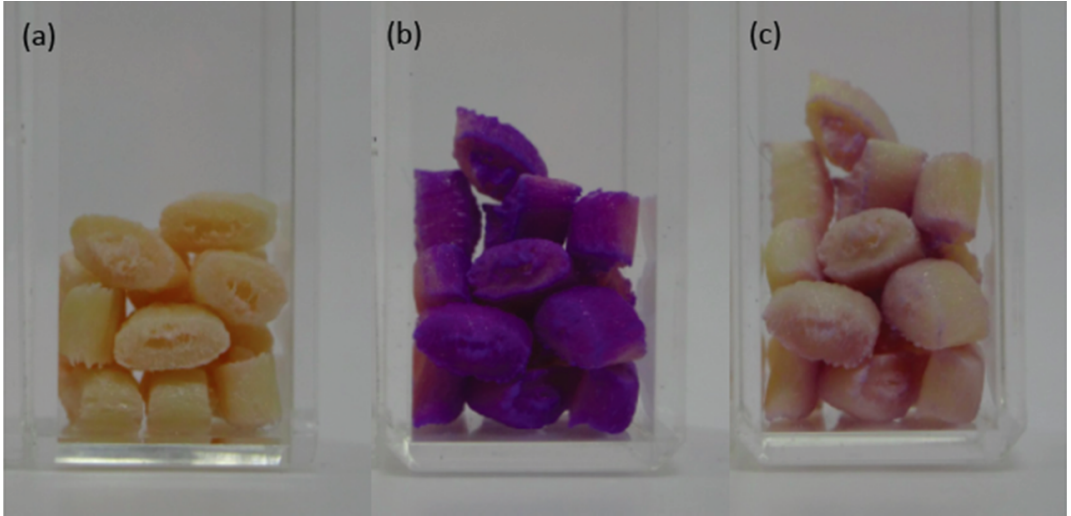

Figure 6. Photochromic behavior of surface-modified PET.A2-B5-C1 (samples in $1 \mathrm{~cm}$ cuvettes). (a) Before UV irradiation, (b) after UV irradiation for $30 \mathrm{~s}$, (c) after relaxation for $30 \mathrm{~min}$.

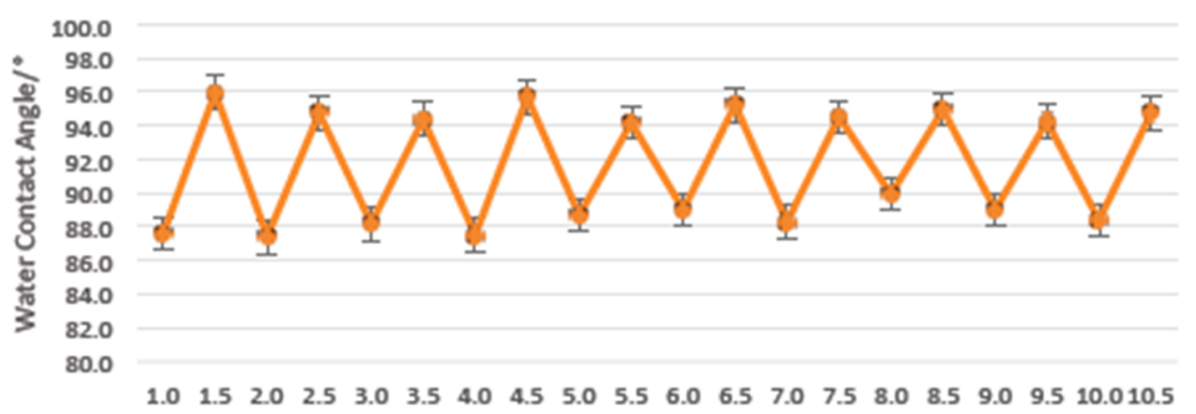

Cycle Number

Figure 7. Water contact angle of surface-modified TPU.A2-B2-C1 over multiple photolysis cycles $($ even cycle $=$ after UV irradiation, odd cycle $=$ relaxation). TPU $=$ thermoplastic polyurethane.

between 30 and $90 \mathrm{~s}$ for 9 in any of ethyl acetate, dichloromethane (DCM), or acetone as solvent).

For surface-modified PET pellets along with UHMWPE and LDPE powders, visible color changes were observable (Figure 6, Table S8 and Figures S14-S16 (Supporting Information)), and the diffuse reflectance UV-vis spectra (Figure S17a, Supporting Information) gave changes in absorption between 500 and 680 $\mathrm{nm}$ although with poorer signal-noise output, and this was due to a combination of the lower surface loading and the physical form of the polymer samples.

The suitability of flat substrates for the introduction of photochromic behavior, in which surface area was further reduced, was then examined; these substrates were also amenable to the measurement of water contact angle (WCA). Some materials showed no significant color change (e.g., PET, PP), but the photochromic PDMS and TPU flat substrates showed evident change in color after UV irradiation (Table S9 and Video S3, Supporting Information). Although both PDMS.A2-B2-C1 and PDMS.A2-B4-C1 showed a similar decrease in $\% \mathrm{~T}$ of about $30 \%$ at $550 \mathrm{~nm}$ in their $\mathrm{UV}-$ vis spectra, WCA measured for the former showed very little change, but for the latter decreased by $4.6^{\circ}$. The nonuniformity in the surface modification and photochromic transformation was reflected in the large \pm error in WCA. Photochromic change for TPU.A2B2-C1 resulted in a decrease in \% $T$ of approximately $35 \%$ at around $569 \mathrm{~nm}$, whereas TPU.A2-B4-C1 registered a decrease of approximately $50 \%$ also around $569 \mathrm{~nm}$; WCA of TPU.A2-B2-C1 and TPU.A2-B4-C1 decreased by 9.1 and $3.8^{\circ}$. These changes are due to a greater proportion of the merocyanine form, which is zwitterionic and hence polar, being present on the surface of the polymer. Of particular interest is that TPU.A2-B2-C1 could be run through multiple photochromic activation-relaxation cycles and without significant loss of water contact angle after 10 cycles (Figure 7).

Although the visible appearance of surface-modified PET and COC did not change before and after UV irradiation, changes in UV-vis spectra were nonetheless observable (Table S9 and Figure S17b, Supporting Information), which were reflected in decreases in WCA values measured for the photochromic PET sample. Similar effects were observed for COC.A2-B2-C1, which gave a decrease in WCA of about $7.5^{\circ}$. This outcome emphasized that although photochromic change might not be detectable by the naked eye, the loading of the surface modification was sufficient to bring about change in WCA and UV-vis absorbance. By contrast, the UV-vis spectra and WCA of PP were similar before and after UV irradiation, indicating that surface modification loading was not sufficient to bring about a detectable photochromic change, and this is consistent with the chemical inertness of PP.

Overall, this work has shown that photochromic effects by surface modification are achievable for a variety of substrates and substrate forms, although optimization of the modifying carbene and the subsequent linking and spiropyran modifying steps may be required, depending upon the underlying polymer substrate.

\section{CONCLUSIONS}

This work has shown that a multistep sequential strategy for the modification of the surface for a variety of polymeric substrates, mediated, first, by carbene insertion chemistry, second, by diazonium coupling with a tethered precursor, and finally by 
coupling to a spiropyran, enables the introduction of a spiropyran at a surface loading density sufficient that macroscopic photochromic and light-controllable wettability phenomena are readily observable. Materials suitable for application in this process include reactive (e.g., polystyrene, poly(ethylene terephthalate)), but also lower surface energy polymers (e.g., polyethylene, polypropylene), which may be in various physical forms (e.g., bead, pellet, powder, sheet). Although the process is particularly highly efficient for high surface area materials, surface modification onto lower surface area substrates is nonetheless sufficiently effective that changes in macroscopic photochromic properties are readily observable; importantly, the approach can be applied in batch processing using thermal carbene activation, or be scaled for large-area processing, which uses photolytic carbene activation. The photochromic modification, manifested macroscopically as color and spectroscopic absorption changes which are significantly slower relative to solution behavior, also lead to surface polarity changes, as shown by contact angle measurement, and such changes can be run over multiple cycles without significant photobleaching or loss of efficacy. Critical is that this outcome is achieved based upon only surface modification of the substrate and does not require dispersion into the bulk of the substrate; such photochromic behavior can be observed at typical surface loading density of ca $10^{12}-10^{13}$ molecules $\mathrm{cm}^{-2}$. This approach compares to noncovalent $^{54}$ and other covalent ${ }^{55}$ methodology suitable for the introduction of optical responsive properties in diverse applications. $^{56,57}$

\section{EXPERIMENTAL SECTION}

General. All reactions that require anhydrous conditions were carried out under nitrogen by standard procedures. All reagents and solvents were purchased from commercial suppliers and were used without further treatment, except for dry THF, which was obtained by passing through a dry alumina column. Analytical thin layer chromatography (TLC) was performed whenever possible with Merck aluminum foil backed TLC sheets, precoated with silica gel 60 F254 and layer thickness of $0.2 \mathrm{~mm}$, and visualized under UV fluorescence $\left(\lambda_{\max }\right.$ $=254 \mathrm{~nm}$ ). Silica gel flash columns were performed on Merck Geduran $60(0.040-0.063 \mathrm{~mm})$ mesh silica gel. ${ }^{1} \mathrm{H},{ }^{13} \mathrm{C}$, COSY, HSQC, and DEPT-135 spectra were recorded on either a Bruker DPX200 (200 MHz) or AVF400 (400 MHz) spectrometer. Chemical shifts $(\delta)$ are reported in parts per million (ppm) relative to various solvent residual peaks and coupling constants in hertz $(\mathrm{Hz})$. Low-resolution mass spectra were obtained on a Fison Platform spectrometer with electrospray ionization (ESI). High-resolution mass spectra were obtained on a Bruker microTOF spectrometer, all reported in Daltons. For compounds in solid, liquid, or oil form, IR spectra were obtained using a Bruker Tensor 27 FT-IR spectrometer. Absorption maxima $\left(\nu_{\max }\right)$ are reported in wavenumbers $\left(\mathrm{cm}^{-1}\right)$ with selected peaks reported. Melting points were measured using a Stuart Scientific SMP1 melting point instrument. Surface analyses of various modified substrates were performed through ATR-IR, performed on a Bio-Rad FTS-6000 with a diamond stage accessory. Combustion analysis was performed by MEDAC Ltd (www.medacltd.com). Solid-state -diffused reflectance UV-vis and solution absorbance UV-vis was performed on Agilent Cary 4000 UV Vis Spectrometer. Pike Veemac Diffuse IR accessory was used with the Spectrometer for Diffused Reflectance UV-vis measurements.
1-(3-lodopropyl)-2,3,3-trimethyl-3H-indol-1-ium iodide.

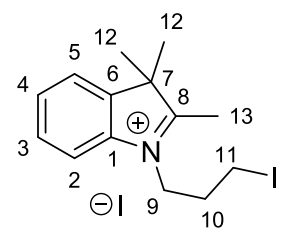

To a solution of 2,3,3-trimethylindolinine $(1.00 \mathrm{~mL}, 6.23 \mathrm{mmol}$, 1.00 equiv), $\mathrm{MeCN}(10 \mathrm{~mL})$ was added and degassed with $\mathrm{N}_{2}$. After adding 1,3-diiodopropane $(2.50 \mathrm{~mL}, 21.8 \mathrm{mmol}, 3.49$ equiv) into the solution, the mixture was refluxed for at least 48 h. After cooling to room temperature, the mixture was then filtered, and the residue was washed with minimal amount of $\mathrm{MeCN}$ and $\mathrm{CHCl}_{3}$ and collected, giving the product as a golden yellow solid (1.46 g, 51\%). Golden yellow solid; mp: 216-217 ${ }^{\circ} \mathrm{C}$. IR (neat): 3434, 2253, 2127, 1665, 1054, 1025, 1004, 823, $761 \mathrm{~cm}^{-1}$; ${ }^{1} \mathrm{H}$ NMR (400 MHz, DMSO- $\left.d_{6}\right): \delta 7.97-8.00(1 \mathrm{H}$, m, H-2), 7.82-7.87 (1H, m, H-5), 7.67 (2H, m, H-3,4), 4.48 $(1 \mathrm{H}, \mathrm{t}, J=7.6 \mathrm{~Hz}, \mathrm{H}-9), 3.43(1 \mathrm{H}, \mathrm{t}, J=7.4 \mathrm{~Hz}, \mathrm{H}-11), 2.86(3 \mathrm{H}$, s, H-13), 2.40 (2H, m, H-10), 1.55 (6H, s, H-12); ${ }^{13} \mathrm{C}(100$ MHz, DMSO- $\left.d_{6}\right): \delta 197.3$ (C-1), 141.8 (C-8), 141.1 (C-6), 129.4 (C-3/4), 128.9 (C-3/4), 123.5 (C-5), 115.2 (C-2), 54.3 (C-7), 48.4 (C-9), 31.0 (C-10), 22.0 (C-12), 14.3 (C-13), 2.3 (C-11). LRMS (ESI) $m / z:[\mathrm{M}-\mathrm{I}]^{+}:$328.1. HRMS (ESI) calculated for $\mathrm{C}_{14} \mathrm{H}_{19} \mathrm{I}_{2} \mathrm{~N} \mathrm{~m} / z[\mathrm{M}-\mathrm{I}]^{+}:$328.0557; found: 328.0560 .

1-(3-lodopropyl)-3,3-dimethyl-2-methyleneindoline.

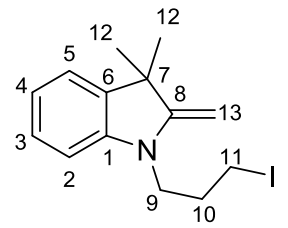

1-(3-Iodopropyl)-2,3,3-trimethyl-3H-indol-1-ium iodide (212 $\mathrm{mg}, 0.466 \mathrm{mmol}, 1.00$ equiv) was suspended in degassed water $(56 \mathrm{~mL})$. Finely ground $\mathrm{NaOH}$ (559 mg, $14.0 \mathrm{mmol}, 30.0$ equiv) was added all at one go. The solution was stirred at room temperature for $1 \mathrm{~h} . \mathrm{Et}_{2} \mathrm{O}(60 \mathrm{~mL})$ was then added and stirred for $30 \mathrm{~min}$. The layers were then separated, and aqueous layer was then extracted with DCM. The organic layers were washed with water separately, then combined, dried over $\mathrm{MgSO}_{4}$, and filtered before concentrating in vacuo to give the products as a dark pink gum (crude yield $261 \mathrm{mg}$, 80\%) which was used without further purification. Dark pink gum; IR (neat): 2965, $2360,1707,1612,1458,1207,745 \mathrm{~cm}^{-1}$. LRMS (ESI) $\mathrm{m} / z$ : [M $+\mathrm{H}]^{+}:$218.2. ${ }^{1} \mathrm{H} \mathrm{NMR}\left(200 \mathrm{MHz}, \mathrm{CDCl}_{3}\right): 7.13-7.19(2 \mathrm{H}, \mathrm{m}$, $\mathrm{H}-3,5), 6.83(1 \mathrm{H}, \mathrm{t}, J=7.3 \mathrm{~Hz}, \mathrm{H}-4), 6.68(1 \mathrm{H}, \mathrm{d}, J=7.6 \mathrm{~Hz}, \mathrm{H}-$ 2), $3.96(2 \mathrm{H}, \mathrm{d}, J=14.5 \mathrm{~Hz}, \mathrm{H}-13), 3.67(2 \mathrm{H}, \mathrm{t}, J=6.7 \mathrm{~Hz}, \mathrm{H}-9)$, $3.26(2 \mathrm{H}, \mathrm{t}, J=6.6 \mathrm{~Hz}, \mathrm{H}-10), 2.24$ (2H, m, H-11), 1.39 (6H, s, $\mathrm{H}-12$ ). LRMS (ESI) $m / z:[\mathrm{M}+\mathrm{H}]^{+}: 328.1$. HRMS (ESI) calculated for $\mathrm{C}_{14} \mathrm{H}_{19} \mathrm{IN} m / z[\mathrm{M}+\mathrm{H}]^{+}:$328.0557; found: 328.0568 . 
$1^{\prime}$-(3-lodopropyl)-3', 3'-dimethyl-6-nitrospiro[chromene-2, $2^{\prime}$-indoline] (5a).

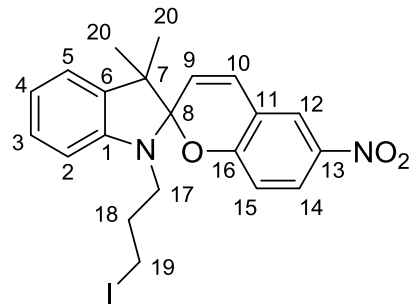

1-(3-Iodopropyl)-3,3-dimethyl-2-methyleneindoline $(190 \mathrm{mg}$, $0.587 \mathrm{mmol}$, 1.00 equiv) was dissolved in $\mathrm{EtOH}(10 \mathrm{~mL})$, followed by addition of 5-nitrosalicylaldehyde (103 mg, 0.616 mmol, 1.05 equiv). The mixture was then sonicated for $2 \mathrm{~h}$, before concentrating in vacuo to remove solvent. The residue was then taken up by DCM and washed with water. The organic layer was dried over $\mathrm{MgSO}_{4}$, filtered, and concentrated in vacuo. Purification by short flash column chromatography (eluted at petrol/EA $=45: 1)$ gave 5 a as a yellow-green oil $(161 \mathrm{mg}, 58 \%$ yield). $\left(R_{f}: 0.80\right.$ in petrol/EA $\left.=5: 1\right)$ yellow-green oil; IR (neat): 2964, 2359, 1611 ( C=C), $1518\left(\mathrm{NO}_{2}\right), 1481,1336\left(\mathrm{NO}_{2}\right)$, $1273,952,808,745 \mathrm{~cm}^{-1}$; ${ }^{1} \mathrm{H}$ NMR $\left(400 \mathrm{MHz}, \mathrm{CDCl}_{3}\right): 8.02-$ 8.05 (2H, m, H-12,14), 7.21 (1H, ddd, $J=7.6,7.6,1.2 \mathrm{~Hz}, \mathrm{H}-3)$, $7.11(1 \mathrm{H}, \mathrm{dd}, J=7.1,1.0 \mathrm{~Hz}, \mathrm{H}-5), 6.96(1 \mathrm{H}, \mathrm{d}, J=10.5 \mathrm{~Hz}, \mathrm{H}-$ 10), $6.91(1 \mathrm{H}, \mathrm{ddd}, J=7.6,7.6,0.7 \mathrm{~Hz}, \mathrm{H}-4), 6.77(1 \mathrm{H}, \mathrm{d}, J=8.3$ $\mathrm{Hz}, \mathrm{H}-15), 6.65(1 \mathrm{H}, \mathrm{d}, J=7.9 \mathrm{~Hz}, \mathrm{H}-2), 5.88(1 \mathrm{H}, \mathrm{d}, J=10.2$ $\mathrm{Hz}, \mathrm{H}-9), 3.12-3.38$ (4H, m, H-17, 19), 2.04-2.27 (2H, m, H18), $1.30(3 \mathrm{H}, \mathrm{s}, \mathrm{H}-20), 1.20(3 \mathrm{H}, \mathrm{s}, \mathrm{H}-20) ;{ }^{13} \mathrm{C}(100 \mathrm{MHz}$, $\left.\mathrm{CDCl}_{3}\right): \delta 159.3(\mathrm{C}-13), 146.8\left(\mathrm{C}_{\text {quat }}\right), 141.0\left(\mathrm{C}_{\text {quat }}\right), 136.0$ $\left(\mathrm{C}_{\text {quat }}\right) 128.5$ (C-10), 127.8 (C-3), 126.0 (C-12/14), 122.8 (C12/14), 121.8 (C-5), 121.7 (C-9), 119.8 (C-4), 118.5 ( $\left.\mathrm{C}_{\text {quat }}\right)$, 115.5 (C-15), 106.8 (C-2), $106.6\left(\mathrm{C}_{\text {quat }}\right), 52.6$ (C-7), 44.1 (C17), 32.5 (C-18), 26.0 (C-20), 19.9 (C-20), 3.2 (C-19). LRMS (ESI) $m / z:[\mathrm{M}+\mathrm{H}]^{+}:$477.1. HRMS (ESI) calculated for $\mathrm{C}_{21} \mathrm{H}_{22} \mathrm{IN}_{2} \mathrm{O}_{3} m / z[\mathrm{M}+\mathrm{H}]^{+}$: 477.0670; found: 477.0669.

6,8-Dibromo-1'-(3-iodopropyl)-3', 3' -dimethylspiro[chromene-2,2'-indoline] (5b).

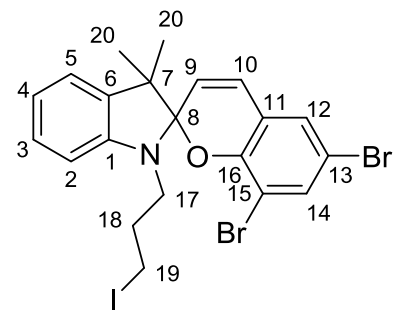

1-(3-Iodopropyl)-3,3-dimethyl-2-methyleneindoline (260 mg, $0.795 \mathrm{mmol}, 1.00$ equiv) was dissolved in $\mathrm{EtOH}(8 \mathrm{~mL})$, followed by addition of 3,5-dibromosalicylaldehyde $(234 \mathrm{mg}$, $0.832 \mathrm{mmol}, 1.05$ equiv). The mixture was then sonicated for 2 $\mathrm{h}$, before concentrating in vacuo to remove solvent. The residue was then taken up by DCM and washed with water. The organic layer was dried over $\mathrm{MgSO}_{4}$, filtered, and concentrated in vacuo. Purification by a short flash column chromatography (eluted at petrol/EA $=55: 1)$ gave $5 \mathbf{b}$ as a green gum $(252 \mathrm{mg}, 54 \%$ yield $)$. $\left(R_{f}: 0.70\right.$ in petrol/EA = 9:1) green gum; IR (neat): 2963,1607 ( $\mathrm{C}=\mathrm{C}), 1484,1446(\mathrm{C}=\mathrm{C}), 1262,893,746 \mathrm{~cm}^{-1}$; ${ }^{1} \mathrm{H}$ NMR $\left(400 \mathrm{MHz}, \mathrm{CDCl}_{3}\right): \delta 7.47(1 \mathrm{H}, \mathrm{d}, J=2.2 \mathrm{~Hz}, \mathrm{H}-14), 7.18(1 \mathrm{H}$, ddd, $J=7.6,7.6,1.3 \mathrm{~Hz}, \mathrm{H}-3), 7.15(1 \mathrm{H}, \mathrm{d}, J=2.5 \mathrm{~Hz}, \mathrm{H}-12)$, $7.08(1 \mathrm{H}, \mathrm{dd}, J=7.4,0.7 \mathrm{~Hz}, \mathrm{H}-5), 6.86(1 \mathrm{H}, \mathrm{ddd}, J=7.3,7.3$, $0.7 \mathrm{~Hz}, \mathrm{H}-4), 6.77(1 \mathrm{H}, \mathrm{d}, J=10.3 \mathrm{~Hz}, \mathrm{H}-10), 6.61(1 \mathrm{H}, \mathrm{d}, J=$ $7.8 \mathrm{~Hz}, \mathrm{H}-2), 5.77(1 \mathrm{H}, \mathrm{d}, J=10.0 \mathrm{~Hz}, \mathrm{H}-9), 3.14-3.38(4 \mathrm{H}, \mathrm{m}$, H-17,19), 2.01-2.29 (2H, m, H-18), 1.31 (3H, s, H-20), 1.17
$(3 \mathrm{H}, \mathrm{s}, \mathrm{H}-20) ;{ }^{13} \mathrm{C}\left(100 \mathrm{MHz}, \mathrm{CDCl}_{3}\right): \delta 149.62,146.71$ (C-8), 136.07, 134.89 (C-16), 128.32 (C-18), 128.07 (C-13), 127.53 (C-2), 122.07 (C-14), 121.70 (C-6), 121.24, 119.35 (C-1), 111.87, 110.17, 106.56 (C-3), 106.12, 52.27, 43.95 (C-21), 32.30 (C-22), 25.66 (C-19/20), 20.40 (C-19/20), 3.80 (C-23). LRMS (ESI) $m / z:[\mathrm{M}+\mathrm{H}]^{+}:$587.9. HRMS (ESI) calculated for $\mathrm{C}_{21} \mathrm{H}_{20}{ }^{79} \mathrm{Br}_{2} \mathrm{INO} m / z[\mathrm{M}+\mathrm{H}]^{+}$: 587.9029; found: 587.9022 .

4,4'-(Hydrazonomethylene)bis( $N, N$-dimethylaniline).<smiles>CN(C)c1ccc(C(=N)c2ccc(N(C)C)cc2)cc1</smiles>

Michler's ketone ( $1.50 \mathrm{~g}, 5.60 \mathrm{mmol}, 1.00$ equiv) was suspended in $\mathrm{EtOH}$. After adding hydrazine monohydrate $(4.06 \mathrm{~mL}, 84.0$ mmol, 15.00 equiv) into the suspension, the reaction mixture was stirred under reflux condition for $72 \mathrm{~h}$. After cooling the reaction mixture to room temperature, the mixture was cooled in ice bath to crystallize out the products, which were then filtered out, washed with minimal amount of 2-propanol and dried, giving white-yellow solid ( $1.22 \mathrm{~g}, 77 \%$ yield). Yellow-white solid. Mp: $153-154^{\circ} \mathrm{C}$. IR: 2802, 1608 ( $\left.=\mathrm{C}\right), 1519$ (C=C), 1341 $(\mathrm{C}-\mathrm{N}), 1190,1166,1061,994,820 ;{ }^{1} \mathrm{H}$ NMR (400 MHz, $\left.\mathrm{CDCl}_{3}\right): \delta 7.40\left(4 \mathrm{H}, \mathrm{m}, \mathrm{H}-2,2^{\prime}\right), 7.19\left(4 \mathrm{H}, \mathrm{m}, \mathrm{H}-2,2^{\prime}\right), 6.83$ $\left(4 \mathrm{H}, \mathrm{m}, \mathrm{H}-3.3^{\prime}\right), 6.65\left(4 \mathrm{H}, \mathrm{m}, \mathrm{H}-3,3^{\prime}\right), 3.03\left(12 \mathrm{H}, \mathrm{s}, \mathrm{H}-5,5^{\prime}\right)$, $2.96\left(12 \mathrm{H}, \mathrm{s}, \mathrm{H}-5,5^{\prime}\right) ;{ }^{13} \mathrm{C}\left(100 \mathrm{MHz}^{\mathrm{CDCl}} \mathrm{CDC}_{3}\right): \delta 151.1(\mathrm{C}=\mathrm{O})$, $150.3(\mathrm{C}=\mathrm{O}), 129.9\left(\mathrm{C}-2,2^{\prime}\right), 127.9\left(\mathrm{C}-2,2^{\prime}\right), 127.7\left(\mathrm{C}_{\text {quat }}\right)$, $120.5\left(\mathrm{C}_{\text {quat }}\right), 112.4\left(\mathrm{C}-3,3^{\prime}\right), 111.7\left(\mathrm{C}-3,3^{\prime}\right), 40.4\left(\mathrm{C}-5,5^{\prime}\right), 40.3$ $\left(\mathrm{C}-5,5^{\prime}\right)$. LRMS (ESI) $m / z$ : $[\mathrm{M}+\mathrm{H}]^{+}:$283.2. HRMS (ESI) calculated for $\mathrm{C}_{17} \mathrm{H}_{23} \mathrm{~N}_{4} m / z[\mathrm{M}+\mathrm{H}]^{+}$: 283.1917; found: 283.1908.

4,4' -(Diazomethylene)bis( $N, N$-dimethylaniline) (3a).<smiles>CN(C)c1ccc(C(=N)c2ccc(N(C)C)cc2)cc1</smiles>

Hydrazone (500 mg, $1.77 \mathrm{mmol}, 1.00$ equiv), $\mathrm{HgO}$ ( $800 \mathrm{mg}$, $3.71 \mathrm{mmol}, 2.00$ equiv), and $\mathrm{Na}_{2} \mathrm{SO}_{4}(640 \mathrm{mg}, 4.42 \mathrm{mmol}, 2.50$ equiv) were added into a RBF wrapped in aluminum foil and stirred in $\mathrm{EtOH}(10 \mathrm{~mL}) . \mathrm{KOH}$ saturated in $\mathrm{EtOH}(3 \mathrm{~mL})$ was then added, and the reaction mixture was stirred in the dark for $18 \mathrm{~h}$. After filtering through a celite pad, the filtrate collected was concentrated in vacuo in the dark and used immediately. The resulting mixture was a dark green slime (crude $440 \mathrm{mg}, 90 \%$ yield). IR (neat): 3389, $2021\left(=\mathrm{N}^{+}=\mathrm{N}^{-}\right.$diazo $), 1610(\mathrm{C}=\mathrm{C})$, 1519 (C=C), 1444, 1370, 1226, 1167, 1070, 945, $820 \mathrm{~cm}^{-1}$.

(Bis(4-methoxyphenyl)methylene)hydrazine.<smiles>COc1ccc(C(=N)c2ccc(OC)cc2)cc1</smiles>

Hydrazine monohydrate ( $2.00 \mathrm{~mL}, 20.6 \mathrm{mmol}, 10.00$ equiv) was added to a suspension of $4,4^{\prime}$-dimethoxybenzophenone $(1.00 \mathrm{~g}$, $4.13 \mathrm{mmol}, 1.00$ equiv) in EtOH, stirred, and refluxed for $24 \mathrm{~h}$. The reaction was then cooled to room temperature, and EtOH was removed in vacuo. The reaction mixture was then extracted with DCM. The organic layer was washed with brine and dried over anhydrous $\mathrm{Na}_{2} \mathrm{SO}_{4}$, filtered, and dried under vacuum 
(alternatively, $10-15 \mathrm{~mL}$ of $\mathrm{H}_{2} \mathrm{O}$ was added into reaction mixture, and EtOH was removed in vacuo until product started to precipitate). The reaction mixture was then placed in ice bath for an hour before the precipitated white solid (912 mg, 86\% crude yield) was collected on a Büchner funnel and dried. White solid; mp: $83-84{ }^{\circ} \mathrm{C}$; ${ }^{1} \mathrm{H} \mathrm{NMR}\left(400 \mathrm{MHz}, \mathrm{CDCl}_{3}\right): \delta 7.41(2 \mathrm{H}$, m, H-2), 7.23 (2H, m, H-2'), 7.05 (2H, m, H-3'), 6.83 (2H, m, $\mathrm{H}-3), 3.88$ (3H, s, H-5/5'), 3.81 (3H, s, H-5/5'); 13C (100 $\left.\mathrm{MHz}, \mathrm{CDCl}_{3}\right): \delta 159.8\left(\mathrm{C}-4 / 4^{\prime}\right), 159.6\left(\mathrm{C}-4 / 4^{\prime}\right), 149.3(\mathrm{C}=$ N), 130.2 (C-2/2'), 127.9 (C-2/2'), 125.0 (C-1,1'), 114.6 (C3/3'), $113.4\left(\mathrm{C}-3 / 3^{\prime}\right), 55.3\left(\mathrm{C}-5 / 5^{\prime}\right), 55.2$ (C-5/5'). LRMS (ESI) $m / z:[\mathrm{M}+\mathrm{H}]^{+}:$257.1. HRMS (ESI) calculated for $\mathrm{C}_{22} \mathrm{H}_{24} \mathrm{~N}_{2} \mathrm{O}_{4} m / z[\mathrm{M}+\mathrm{H}]^{+}: 257.1285$; found: 257.1278 .

Synthesis of $4,4^{\prime}$-(Diazomethylene)bis(methoxybenzene) (3b).

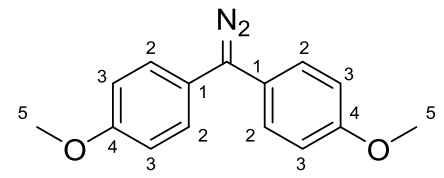

Hydrazone ( $1.00 \mathrm{~g}, 3.90 \mathrm{mmol}, 1.00$ equiv) was stirred with $\mathrm{MnO}_{2}$ (882 mg, $10.14 \mathrm{mmol}, 2.60$ equiv) and $\mathrm{Na}_{2} \mathrm{SO}_{4}$ (776 mg, $5.46 \mathrm{mmol}, 1.40$ equiv) in THF $(10 \mathrm{~mL}) . \mathrm{KOH}$ saturated in $\mathrm{EtOH}(0.20 \mathrm{~mL})$ was then added to the reaction mixture, which was stirred in the dark for $18 \mathrm{~h}$. The mixture is then filtered through a celite pad, eluted using DCM. The filtrate was concentrated and dried in vacuo (in the dark) to give a dark purple solid. Dark purple solid; mp: $88-90^{\circ} \mathrm{C}$; IR (neat): 2954 , 2836, $2027(\mathrm{~N}=\mathrm{N}), 1606(\mathrm{C}=\mathrm{C}), 1507(\mathrm{C}=\mathrm{C}), 1466,1441$, 1244, 1178, 1027, $830 \mathrm{~cm}^{-1}$; ${ }^{1} \mathrm{H}$ NMR $\left(200 \mathrm{MHz}, \mathrm{CDCl}_{3}\right): \delta$ $7.20(4 \mathrm{H}, \mathrm{m}, \mathrm{H}-2), 6.96(4 \mathrm{H}, \mathrm{m}, \mathrm{H}-3) 3.83(6 \mathrm{H}, \mathrm{s}, \mathrm{H}-5) ;{ }^{13} \mathrm{C}(50$ $\mathrm{MHz}, \mathrm{CDCl}_{3}$ ): $\delta 157.7$ (C-4), 126.5 (C-2), 121.5 (C-1), 114.8 (C-3), 53.4 (C-5). HRMS (TOF MS FI+) calculated for $\mathrm{C}_{15} \mathrm{H}_{14} \mathrm{~N}_{2} \mathrm{O}_{2} m / z[\mathrm{M}+\mathrm{H}]^{+}:$254.1055; found: 254.1049.

General Method (A): H-Acid Test for Presence of Diazonium Functionality. A sample of the diazonium salt solution (adjusted to about $\mathrm{pH} 4$ using $\mathrm{NaOAc}$ ) was added into a suspension $(0.5 \mathrm{~mL})$ of $\mathrm{H}$-acid (4-amino-5-hydroxynaphthalene-2,7-disulfonic acid) $/ \mathrm{H}_{2} \mathrm{O}(1: 1 \mathrm{v} / \mathrm{v})$. Upon standing for some time, the beige color suspension turning dark purple would indicate the presence of diazonium functionality.

General Method (B): Diazonium Salt Formation. The corresponding amine 4 (1.00 equiv) was dissolved solvent (EtOH or THF $\left./ \mathrm{H}_{2} \mathrm{O}=1: 1\right)(6-10 \mathrm{~mL}) . \mathrm{HCl}(3 \mathrm{M}, 2.00$ equiv) was added into the mixture and stirred in ice bath for $5 \mathrm{~min}$. $\mathrm{NaNO}_{2}$ (1.20 equiv) dissolved in $\mathrm{H}_{2} \mathrm{O}(1 \mathrm{~mL})$ was then added into the cold mixture. The mixture was stirred in ice bath for 30 min before $\mathrm{H}$-acid was performed to test for presence of diazonium salt. The diazonium salt reaction mixture was used immediately.
Synthesis of 1-(3-(4-Methoxyphenoxy)propyl)-3,3-dimethyl-6' -nitro-1' $H$-spiro[indoline-2,2' -naphthalene] (7).

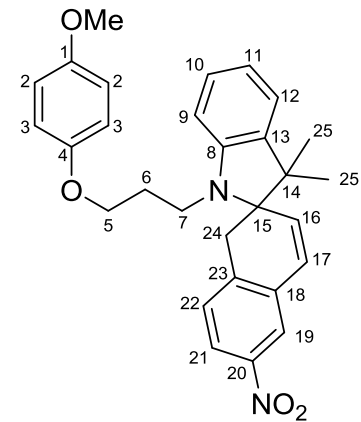

4-Methoxyphenol 6 ( $57 \mathrm{mg}, 0.21 \mathrm{mmol}, 1$ equiv) and spiropyran 5 a ( $119 \mathrm{mg}, 0.25 \mathrm{mmol}, 1.2$ equiv) were dissolved in $\mathrm{MeCN}$ ( 15 $\mathrm{mL}) . \mathrm{K}_{2} \mathrm{CO}_{3}$ was added into the mixture and refluxed for $5 \mathrm{~h}$. After cooling reaction mixture to room temperature, the organic solvent was removed in vacuo. Water was then added, and DCM was used for extraction. The organic layers were collected and combined, dried over $\mathrm{MgSO}_{4}$, concentrated in vacuo, and purified on flash column. Product 7 was eluted with petrol 4060/EA = 35:1. $\left(R_{f}=0.36\right.$ in petrol/EA = 9:1 $)$. Red oil; IR (neat): 2963, 1610 ( C=C), 1508 ( $=\mathrm{C}=$ ), 1482, $1336\left(\mathrm{NO}_{2}\right), 1272$, 1232, 1165, 1090, 1033, $950 \mathrm{~cm}^{-1}$; ${ }^{1} \mathrm{H}$ NMR $(400 \mathrm{MHz}$, $\left.\mathrm{CDCl}_{3}\right): \delta 7.98-8.03(2 \mathrm{H}, \mathrm{m}, \mathrm{H}-18,20), 7.20(1 \mathrm{H}, \mathrm{ddd}, J=7.6$, 7.6, $1.2 \mathrm{~Hz}, \mathrm{H}-10), 7.11(1 \mathrm{H}, \mathrm{dd}, J=7.1,0.7 \mathrm{~Hz}, \mathrm{H}-12), 6.89$ $(1 \mathrm{H}, \mathrm{dd}, J=7.2,7.2 \mathrm{~Hz}, \mathrm{H}-11), 6.78-6.86(5 \mathrm{H}, \mathrm{m}, \mathrm{H}-2,3,16)$, $6.74(1 \mathrm{H}, \mathrm{d}, J=8.8 \mathrm{~Hz}, \mathrm{H}-21), 6.65(1 \mathrm{H}, \mathrm{d}, J=7.8 \mathrm{~Hz}, \mathrm{H}-9)$, $5.77(1 \mathrm{H}, \mathrm{d}, J=10.5 \mathrm{~Hz}, \mathrm{H}-15), 3.95(2 \mathrm{H}, \mathrm{t}, J=5.9 \mathrm{~Hz}, \mathrm{H}-5)$, $3.70(3 \mathrm{H}, \mathrm{s}, \mathrm{H}-24), 3.45-3.53(1 \mathrm{H}, \mathrm{m}, \mathrm{H}-7), 3.29-3.36(1 \mathrm{H}, \mathrm{m}$, H-7), 2.00-2.14 (2H, m, H-6), 1.29 (3H, s, H-23), 1.18 (3H, s, $\mathrm{H}-23) ;{ }^{13} \mathrm{C}\left(100 \mathrm{MHz}, \mathrm{CDCl}_{3}\right): \delta 159.5$ (C-19), $153.8\left(\mathrm{C}_{\text {quat }}\right)$, $152.7\left(\mathrm{C}_{\text {quat }}\right), 147.0\left(\mathrm{C}_{\text {quat }}\right), 140.9\left(\mathrm{C}_{\text {quat }}\right), 136.0\left(\mathrm{C}_{\text {quat }}\right), 128.0$ (C-16), 127.8 (C-10), 125.8 (C-18/20), 122.6 (C-18/20), 121.8 (C-15), 121.7 (C-12), 119.5 (C-11), 118.5 (C $\left.\mathrm{C}_{\text {quat }}\right), 115.5$ (C-21), 115.1 (C-2/3), 114.6 (C-2/3), 106.7 (C-9), 65.2 (C-6), 55.7 (C-24), $52.6\left(\mathrm{C}_{\text {quat }}\right), 40.2$ (C-7), 28.5 (C-6), 25.9 (C-23), 19.8 (C-23). HRMS (ESI) calculated for $\mathrm{C}_{28} \mathrm{H}_{28} \mathrm{~N}_{2} \mathrm{O}_{5} \mathrm{~m} / z[\mathrm{M}+$ $\mathrm{H}]^{+}$: 473.20710; found: 473.20638.

Synthesis of 3-( $3^{\prime}, 3^{\prime}-$ Dimethyl-6-nitrospiro[chromene-2,2'-indolin]-1'-yl)propyl 4-Hydroxybenzoate (9).

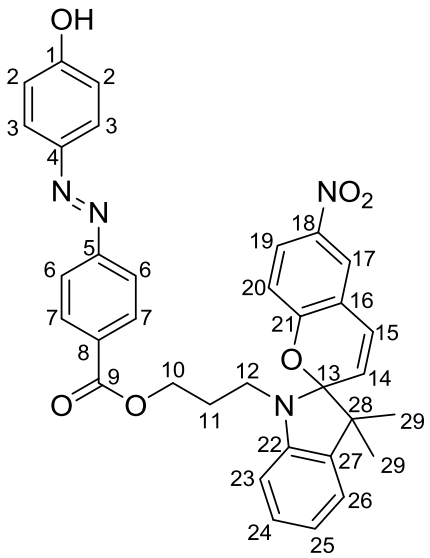

Azo derivative 8 (51 mg, $0.21 \mathrm{mmol}, 1.00$ equiv) was stirred together with $5 \mathrm{a}\left(100 \mathrm{mg}, 0.21 \mathrm{mmol}, 1.00\right.$ equiv) and $\mathrm{K}_{2} \mathrm{CO}_{3}$ (43 mg, $0.32 \mathrm{mmol}, 1.50$ equiv) in DMSO for $6 \mathrm{~h}$. Water was then added into the solution and extracted repeatedly with 
DCM. The organic layers were dried over $\mathrm{MgSO}_{4}$ concentrated in vacuo and purified though using flash column chromatography. Product 9 eluted at petrol 40-60/EA $=15: 1 .\left(R_{f}=0.36\right.$ in petrol $40-60 / \mathrm{EA}=3: 1)$ orange-red solid $(72 \%$ yield); IR (neat): 3363, 2965, 2360, 1716, 1652, 1605, 1518, 1481, 1381, 1336, 1274, 1165, 1138, 1012, 908, $773 \mathrm{~cm}^{-1}$; ${ }^{1} \mathrm{H}$ NMR (400 $\left.\mathrm{MHz} \mathrm{CDCl}_{3}\right): \delta 8.09-8.12(2 \mathrm{H}, \mathrm{m}, \mathrm{H}-7), 8.02(1 \mathrm{H}, \mathrm{dd}, J=8.8$, $2.7 \mathrm{~Hz}, \mathrm{H}-19), 7.88-7.97$ (5H, m, H-3, 6, 17), 7.121 (1H, ddd, $=7.6,7.6,1.2 \mathrm{~Hz}, \mathrm{H}-24), 7.12(1 \mathrm{H}, \mathrm{dd}, J=7.1,0.7 \mathrm{~Hz}, \mathrm{H}-26)$, 6.97-7.01 (2H, m, H-2), $6.92(1 \mathrm{H}, \mathrm{ddd}, J=7.6,7.6,0.7 \mathrm{~Hz}, \mathrm{H}-$ 25), $6.77(1 \mathrm{H}, \mathrm{d}, J=8.8 \mathrm{~Hz}, \mathrm{H}-20), 6.76(1 \mathrm{H}, \mathrm{d}, J=10.3 \mathrm{~Hz}, \mathrm{H}-$ 15), $6.65(1 \mathrm{H}, \mathrm{d}, J=7.6 \mathrm{~Hz}, \mathrm{H}-23), 5.87(1 \mathrm{H}, \mathrm{d}, J=10.5 \mathrm{~Hz}, \mathrm{H}-$ 14), 4.36-4.47 (2H, m, H-10), 3.30-3.48 (2H, m, H-12), 2.05-2.22 (2H, m, H-11), 1.29 (3H, s, H-29), 1.20 (3H, s, H$29) ;{ }^{13} \mathrm{C}\left(100 \mathrm{MHz}, \mathrm{CDCl}_{3}\right): \delta 166.1\left(\mathrm{C}_{\text {quat }}\right), 159.4\left(\mathrm{C}_{\text {quat }}\right)$, $159.2\left(\mathrm{C}_{\text {quat }}\right), 155.5\left(\mathrm{C}_{\text {quat }}\right), 147.1\left(\mathrm{C}_{\text {quat }}\right), 146.8\left(\mathrm{C}_{\text {quat }}\right), 141.0$ $\left(\mathrm{C}_{\text {quat }}\right), 136.1\left(\mathrm{C}_{\text {quat }}\right), 130.9\left(\mathrm{C}_{\text {quat }}\right), 130.5(\mathrm{C}-7), 128.2(\mathrm{C}-15)$, 127.8 (C-24), 125.9 (C-19), 125.5 (C-6), 122.7 (C-17), 122.4 (C-3), 121.8 (C-26), 121.6 (C-14), 119.8 (C-25), $118.3\left(\mathrm{C}_{\text {quat }}\right)$, 116.0 (C-2), $115.6(\mathrm{C}-2), 106.7\left(\mathrm{C}_{\text {quat }}\right), 106.6(\mathrm{C}-23), 62.6(\mathrm{C}-$ 10), 52.5 ( $\mathrm{C}_{\text {quat }}$ ), 40.4 (C-12), 27.9 (C-11), 26.0 (C-29), 19.9 (C-29). HRMS (ESI) calculated for $\mathrm{C}_{34} \mathrm{H}_{30} \mathrm{~N}_{4} \mathrm{O}_{6} \mathrm{~m} / z[\mathrm{M}+$ $\mathrm{Na}]^{+}$: 613.2576; found: 613.20546.

Polymer Modification. General Method (C): Polymer Surface Modification. For a $20 \mathrm{w} / \mathrm{w} \%$ loading, the diaryldiazo compound ( $1.00 \mathrm{~g}$ ) was suspended in $\mathrm{Et}_{2} \mathrm{O}$ and swirled in the dark. Blank polymers $(\sim 5.00 \mathrm{~g})$ were added into the suspension and swirled for homogenous coverage of the beads with the compound. Solvent was removed carefully and slowly in vacuo. The flask was heated to $120{ }^{\circ} \mathrm{C}$ for $30 \mathrm{~min}$ (or until all of the beads have changed color), then cooled to room temperature. The beads were washed thoroughly with acetone and water until no color was observed to be washed out.

General method (D): Coupling of Diazonium Salt Compounds on Modified Surface of Polymers. Functionalized polymers $(\sim 2.50 \mathrm{~g})$ were added into the diazonium salt suspension $(\sim 375 \mathrm{mg}$ in $10 \mathrm{~mL}$ solvent $)$ at $0{ }^{\circ} \mathrm{C}$ and swirled in the dark. The mixture was then left in the fridge at $4{ }^{\circ} \mathrm{C}$ to stand for $18-20 \mathrm{~h}$. The polymers were filtered and washed thoroughly with acetone and water until no color was observed to be washed out $[15 \mathrm{w} / \mathrm{w} \%$ loading: assuming $80 \%$ conversion of amines to diazonium salts from General Method (B)]

General Method (E): Hybridization of Modified Polymers with Spiropyran. For a $10 \mathrm{w} / \mathrm{w} \%$ loading, functionalized polymers from General Method (D) $(\sim 1 \mathrm{~g})$ were refluxed with 6a $(100 \mathrm{mg})$ and $\mathrm{K}_{2} \mathrm{CO}_{3}$ in $\mathrm{MeCN}$ for $5 \mathrm{~h}$. The mixture was then cooled to room temperature. The polymers were then filtered and washed thoroughly with acetone and water until no color was observed to be washed out (alternatively, polymers were stirred in $\mathbf{6 b}$ with $\mathrm{K}_{2} \mathrm{CO}_{3}$ for $18 \mathrm{~h}$ in acetone or DMSO at room temperature).

Procedure for Photochromic Activity Measurement. For Solution. The photochromic compound was first dissolved in the solvent and left to stand in light for at least $1 \mathrm{~h}$. The solution was transferred carefully into a quartz vial using a syringe. UVvis absorbance data were measured. The quartz vial containing the solution was carefully transferred to the UV box for UV irradiation at $360-375 \mathrm{~nm}$ for $1 \mathrm{~min}$ and transferred immediately back to the UV-vis spectrophotometer for absorbance measurement.

For Beads, Pellets, Powders. The sample was first transferred carefully into the small sample holder for the diffused reflectance accessory. A UV-vis diffused reflectance spectrum was recorded. The sample holder was transferred from the UV-vis spectrophotometer to the UV box where the photochromic sample was exposed to UV irradiated at $360-375 \mathrm{~nm}$ for $1 \mathrm{~min}$. The sample holder was then transferred immediately back to the UV-vis spectrophotometer for diffused reflectance measurement.

For Flat Samples. UV-vis transmittance spectrum for photochromic flat substrates was first collected. The sample was UV irradiated at $360-375 \mathrm{~nm}$ for $1 \mathrm{~min}$ and transferred back to the UV-vis spectrophotometer for another transmittance measurement.

\section{ASSOCIATED CONTENT}

\section{Supporting Information}

The Supporting Information is available free of charge on the ACS Publications website at DOI: 10.1021/acsomega.8b02521.

Compound and polymer characterization data, and photographs of modified materials (PDF)

Photochromism forXAD4.A1-B5-C1 (AVI)

Photochromism for spiropyran unit 5a in solution (AVI)

Photochromism for modified PDMS substrate (AVI)

\section{AUTHOR INFORMATION}

\section{Corresponding Authors}

*E-mail: mark.moloney@chem.ox.ac.uk (M.G.M.).

*E-mail: ylwu@SIMTech.a-star.edu.sg (L.Y.L.W.).

ORCID

Mark G. Moloney: 0000-0002-4440-3632

Notes

The authors declare no competing financial interest.

\section{ACKNOWLEDGMENTS}

The authors would like to acknowledge ASTAR for funding to S.C.

\section{REFERENCES}

(1) Zhang, P.; Meng, J. B.; Li, X. L.; Matsuura, T.; Wang, Y. M. Synthesis and Photochromism of Photochromic Spiro Compounds having a Reactive Pendant Group. J. Heterocycl. Chem. 2002, 39, 179184.

(2) Wang, D.; Wang, X. Amphiphilic Azo Polymers: Molecular Engineering, Self-assembly and Photoresponsive Properties. Prog. Polym. Sci. 2013, 38, 271-301.

(3) Barié, N.; Rapp, M.; Sigrist, H.; Ache, H. J. Covalent Photolinkermediated Immobilization of an Intermediate Dextran layer to Polymercoated Surfaces for Biosensing Applications. Biosens. Bioelectron. 1998, $13,855-860$.

(4) Huang, W.; Yang, J.; Wang, X.; Huang, W.; Yang, H.; Wang, G.; Jiang, B.; Li, F.; Komarneni, S.; et al. Light-Temperature Dual Stimuli Lead to Self-Assembly of Hyperbranched Azobenzene-terminated Poly(N-isopropylacrylamide). Polymers 2016, 8, 183-200.

(5) Goddard, J. M.; Hotchkiss, J. H. Polymer Surface Modification for the Attachment of Bioactive Compounds. Prog. Polym. Sci. 2007, 32, 698-725.

(6) Cen, L.; Neoh, K. G.; Kang, E. T. Surface Functionalization Technique for Conferring Antibacterial Properties to Polymeric and Cellulosic Surfaces. Langmuir 2003, 19, 10295-10303.

(7) Li, D.; Zheng, Q.; Wang, Y.; Chen, H. Combining Surface Topography with Polymer Chemistry: Exploring New Interfacial Biological Phenomena. Polym. Chem. 2014, 5, 14-24.

(8) Florea, L.; Diamond, D.; Benito-Lopez, F. Photo-Responsive Polymeric Structures Based on Spiropyran. Macromol. Mater. Eng. 2012, 297, 1148-1159. 
(9) Malatesta, V.; Neri, C.; Wis, M. L.; Montanari, L.; Millini, R. Thermal and Photodegradation of Photochromic Spiroindolinenaphthooxazines and -pyrans: Reaction with Nucleophiles. Trapping of the Merocyanine Zwitterionic Form. J. Am. Chem. Soc. 1997, 119, 34513455.

(10) Natali, M.; Aakeroy, C.; Desper, J.; Giordani, S. The Role of Metal Ions and Counterions in the Switching Behavior of a Carboxylic Acid Functionalized Spiropyran. Dalton Trans. 2010, 39, 8269-8277.

(11) Bossi, M. L.; Murgida, D. H.; Aramendia, P. F. Photoisomerization of Azobenzenes and Spirocompounds in Nematic and in Twisted Nematic Liquid Crystals. J. Phys. Chem. B 2006, 110, 13804-13811.

(12) Guo, X.; Zhou, Y.; Zhang, D.; Yin, B.; Liu, Z.; Liu, C.; Lu, Z.; Huang, Y.; Zhu, D. 7-Trifluoromethylquinoline-Functionalized Luminescent Photochromic Spiropyran with the Stable Merocyanine Species Both in Solution and in the Solid State. J. Org. Chem. 2004, 69, 89248931.

(13) Nammoonnoy, J.; Koesdjojo, M. T.; Frederick, R. T.; Remcho, V. T. In 15th International Conference on Miniaturized Systems for Chemistry and Life Sciences; Seattle, Washington, 2011.

(14) Wojtyk, J. T. C.; Wasey, A.; Xiao, N.-N.; Kazmaier, P. M.; Hoz, S.; Yu, C.; Lemieux, R. P.; Buncel, E. Elucidating the Mechanisms of Acidochromic Spiropyran-Merocyanine Interconversion. J. Phys. Chem. A 2007, 111, 2511-2516.

(15) Hobley, J.; Malatesta, V. Energy Carrier to TTC-TTT Isomerisation for the Merocyanine of a Photochromic Spiropyran. Phys. Chem. Chem. Phys. 2000, 2, 57-59.

(16) Keum, S. R.; Hur, M. S.; Kazmaier, P. M.; Buncel, E. Nonactivated Arylazoindolinobenzospiropyran Derivatives. Part 21: Preparation and Kinetic Measurements of the Spiro-ring Formation from the Merocyanine Form. Bull. Korean Chem. Soc. 1999, 20, 14641468.

(17) Beyer, C.; Wagenknecht, H.-A. Synthesis of Spiropyrans As Building Blocks for Molecular Switches and Dyads. J. Org. Chem. 2010, $75,2752-2755$.

(18) York, M.; Evans, R. A. Synthesis and Properties of 1,3,3Trimethylspiro[indoline-2,30-naphtho[2,1-b] [1,4] oxazin]-60-amine, a Novel, Red Colouring Photochromic Spirooxazine. Tetrahedron Lett. 2010, 51, 2195-2197.

(19) Katsonis, N.; Lubomska, M.; Pollard, M. M.; Feringa, B. L.; Rudolf, P. Synthetic Light-activated Molecular Switches and Motors on Surfaces. Prog. Surf. Sci. 2007, 82, 407-434.

(20) Wagner, N.; Theato, P. Light-induced Wettability Changes on Polymer Surfaces. Polymer 2014, 55, 3436-3453.

(21) Calero, P.; Aznar, E.; Lloris, J. M.; Marcos, M. D.; MartınezManez, R.; Ros-Lis, J. V.; Soto, J.; Sancenon, F. Chromogenic Silica Nanoparticles for the Colorimetric Sensing of Long-chain Carboxylates. Chem. Commun. 2008, 1668-1670.

(22) Athanassiou, A.; Lygeraki, M. I.; Pisignano, D.; Lakiotaki, K.; Varda, M.; Mele, E.; Fotakis, C.; Cingolani, R.; Anastasiadis, S. H. Photocontrolled Variations in the Wetting Capability of Photochromic Polymers Enhanced by Surface Nanostructuring. Langmuir 2006, 22, 2329.

(23) Edahiro, J.; Sumaru, K.; Tada, Y.; Ohi, K.; Takagi, T.; Kameda, M.; Shinbo, T.; Kanamori, T.; Yoshimi, Y. In Situ Control of Cell Adhesion Using Photoresponsive Culture Surface. Biomacromolecules 2005, 6, 970-974.

(24) Andersson, J.; Li, S. M.; Lincoln, P.; Andreasson, J. Photoswitched DNA-Binding of a Photochromic Spiropyran. J. Am. Chem. Soc. 2008, 130, 11836-11837.

(25) Vlassiouk, I.; Park, C.-D.; Vail, S. A.; Gust, D.; Smirnov, S. Control of Nanopore Wetting by a Photochromic Spiropyran - a LightControlled Valve andElectrical Switch. Nano Lett. 2006, 6, 1013-1017.

(26) Higuchi, A.; Hamamura, A.; Shindo, Y.; Kitamura, H.; Yoon, B. O.; Mori, T.; Uyama, T.; Umezawa, A. Photon-modulated changes of cell attachments on poly(spiropyran-comethylmethacrylate) membranes. Biomacromolecules 2004, 5, 1770-1774.

(27) Shiraishi, Y.; Itoh, M.; Hirai, T. Thermal Isomerization of Spiropyran to Merocyanine in Aqueous Media and its Application to
Colorimetric Temperature Indication. Phys. Chem. Chem. Phys. 2010, 12, 13737-13745.

(28) Shiraishi, Y.; Adachi, K.; Itoh, M.; Hirai, T. Spiropyran as a Selective, Sensitive, and Reproducible Cyanide Anion Receptor. Org. Lett. 2009, 11, 3482-3485.

(29) Jin, L. M.; Li, Y. N.; Ma, J.; Li, Q. A. Synthesis of Novel Thermally Reversible Photochromic Axially Chiral Spirooxazines. Org. Lett. 2010, $12,3552-3555$

(30) Rosario, R.; Gust, D.; Garcia, A. A.; Hayes, M.; Taraci, J. L.; Clement, T.; Dailey, J. W.; Picraux, S. T. Lotus Effect Amplifies LightInduced Contact Angle Switching. J. Phys. Chem. B 2004, 108, 1264012642 .

(31) Zhang, X.; Hou, L.; Samorì, P. Coupling carbon nanomaterials with photochromic molecules for the generation of optically responsive materials. Nat. Commun. 2016, 7, No. 11118.

(32) Merino, E. Synthesis of Azobenzenes: the Coloured Pieces of Molecular Materials. Chem. Soc. Rev. 2011, 40, 3835-3853.

(33) Ercole, F.; Davis, T. P.; Evans, R. A. Photo-responsive Systems and Biomaterials: Photochromic Polymers, Light-triggered Selfassembly, Surface Modification, Fluorescence Modulation and Beyond. Polym. Chem. 2010, 1, 37-54.

(34) Kulawardana, E. U.; Kuruwita-Mudiyanselage, T.; Neckers, D. C. Dual Responsive Poly(N-isopropylacrylamide) Hydrogels Having Spironaphthoxazines as Pendant Groups. J. Polym. Sci., Part A: Polym. Chem. 2009, 47, 3318-3325.

(35) De Sousa, F. B.; Guerreiro, J. D. T.; Ma, M.; Anderson, D. G.; Drum, C. L.; Sinisterra, R. D.; Langer, R. Photo-response Behavior of Electrospun Nanofibers Based on Spiropyran-cyclodextrin Modified Polymer. J. Mater. Chem. 2010, 20, 9910-9917.

(36) Ercole, F.; Malic, N.; Davis, T. P.; Evans, R. A. Optimizing the Photochromic Performance of Naphthopyrans in a Rigid Host Matrix using Poly(dimethylsiloxane) Conjugation. J. Mater. Chem. 2009, 19, $5612-5623$

(37) Leonard, D.; Moloney, M. G.; Thompson, C. Chemical Modification of Materials by Reaction with Diaryl Diazomethanes. Tetrahedron Lett. 2009, 50, 3499-3502.

(38) Yang, P. F.; Moloney, M. G. Surface Modification of Polymers with Bis(arylcarbene)s from Bis(aryldiazomethane)s: Preparation, Dyeing and Characterization. RSC Adv. 2016, 6, 111276-111290.

(39) Awenat, K. M.; Davis, P. J.; Moloney, M. G.; Ebenezer, W. A Chemical Method for the Surface Functionalisation of Polymers. Chem. Commun. 2005, 990-992.

(40) Wang, H.; Griffiths, J.-P.; Egdell, R. G.; Moloney, M. G.; Foord, J. S. Chemical Functionalization of Diamond Surfaces by Reaction with Diaryl Carbenes. Langmuir 2008, 24, 862-868.

(41) Choong, C.; Griffiths, J.-P.; Moloney, M. G.; Triffitt, J.; Swallow, D. Direct Introduction of Phosphonate by the Surface Modification of Polymers Enhances Biocompatibility. React. Funct. Polym. 2009, 69, $77-85$.

(42) Nelson, G. W.; Parker, E. M.; Singh, K.; Blanford, C. F.; Moloney, M. G.; Foord, J. S. Surface Characterization and in situ Protein Adsorption Studies on a Carbene-modified Polymer Surface. Langmuir 2015, 31, 11086-11096.

(43) Choong, C.; Foord, J. S.; Griffiths, J.-P.; Parker, E. M.; Luo, B.; Bora, M.; Moloney, M. G. Post-polymerisation Modification of Surface Chemical Functionality and its Effect on Protein Binding. New J. Chem. 2012, 36, 1187-1200.

(44) Yang, P. F.; Moloney, M. G. Surface Modification using Crosslinking of Diamine and a Dis(diarylcarbene): Synthesis, Characterization, and Antibacterial Activity via Binding Hydrogen Peroxide. RSC Adv. 2017, 7, 29645-29655.

(45) Bagwell, C. L.; Leonard, D. M. L.; Griffiths, J.-P.; Moloney, M. G.; Stratton, N. J.; Travers, D. P. Post-Polymerization Modification of Materials using Diaryldiazomethanes: Changes to Surface Macroscopic Properties. Macromol. React. Eng. 2014, 8, 170-180.

(46) Griffiths, J. P.; Maliha, B.; Moloney, M. G.; Thompson, A. L.; Hussain, I. Surface Functional Polymers by Post-Polymerization Modification using Diarylcarbenes: Introduction, Release and Regen- 
eration of Hydrogen Peroxide and Bactericidal Activity. Langmuir 2010, 26, 14142-14153.

(47) Yang, P. F.; Moloney, M. G.; Zhang, F.; Ji, W. Surface Hydrophobic Modification of Polymers with Fluorodiazomethanes. Mater. Lett. 2018, 210, 295-297.

(48) Griffiths, J.-P.; Leonard, D. M. L.; Moloney, M. G.; Stratton, N. J. Control Of Wetting Behavior Using Post-Polymerization Modifications Of Surface Chemical Functionality. J. Mol. Eng. Mater. 2012, 1, No. 1250002.

(49) Aphaiwong, A.; Moloney, M. G.; Christlieb, M. Surface Functional Polymer Library by Post-Polymerisation Modification using Diarylmethylenes: Metal Ligand Catch and Release. J. Mater. Chem. 2012, 22, 24627-24636.

(50) Hu, Z.; Shao, Q.; Moloney, M. G.; Xu, X. R.; Zhang, D. Y.; Li, J.; Zhang, C. H.; Huang, Y. D. Nondestructive Functionalization of Graphene by Surface-Initiated Atom Transfer Radical Polymerization: An Ideal Nanofiller for Poly(p-phenylene benzobisoxazole) Fibers. Macromolecules 2017, 50, 1422-1429.

(51) Luksirikul, P.; Ballesteros, B.; Tobias, G.; Moloney, M. G.; Green, M. L. H. pH-Triggered Release of Materials from Single-walled Carbon Nanotubes using Dimethylamino-functionalized Fullerenes as Removable "Corks". Carbon 2010, 48, 1912-1917.

(52) Chng, S.; Parker, E. M.; Griffiths, J.-P.; Moloney, M. G.; Wu, L. Y. L. A Study of Diazonium Couplings with Aromatic Nucleophiles Both in Solution and on a Polymer Surface. Appl. Surf. Sci. 2017, 401, 181189.

(53) Pavia, D. L.; Lampman, G. M.; Kriz, G. S.; Vyvyan, J. A. Introduction to Spectroscopy; Cengage Learning, 2008.

(54) Bremer, M.; Reinke, R.; Hesseler, B.; Taale, M.; Ingwersen, D.; Schwarzer, S.; Selhuber-Unkel, C.; Gerken, M. Noncovalent Spiropyran Coatings for Photoinduced Wettability Switching. J. Nanomater. 2017, No. 6498601.

(55) Piech, M.; George, M. C.; Bell, N. S.; Braun, P. V. Patterned Colloid Assembly by Grafted Photochromic Polymer Layers. Langmuir 2006, 22, 1379.

(56) Crano, J. C.; Flood, T.; Knowles, D.; Kumar, A.; Gemert, B. V. Photochromic compounds: Chemistry and application in ophthalmic lenses. Pure Appl. Chem. 1996, 68, 1395-1398.

(57) Wilson, A. E. J. Applications of photochromic polymer films. Phys. Technol. 1984, 15, 232. 